\title{
CLONAL PROPAGATION OF COCONUT: IMPROVED CULT,URE CONDITIONS FOR RHYZOGENESIS
}

\author{
S C FERNANDO and C K GAMAGE
}

Coconut Research Institute, Lunuwila, Sri Lanka'

\begin{abstract}
Emphasis has recently been placed on improving culture conditions at the rooting stage of the coconut (Cocos nucifera $\mathrm{L}$ ) cloning procedure. In these experiments shoots for rooting were obtained by culturing shoot apices.

The effect of auxins (IAA, NAA, IBA), carbohydrate sources (glucose, fructose, sucrose), lighting conditions and dark treatment on rooting were tested. Dip treatment of shoots in $10^{-4} \mathrm{M}$ IAA solution for three to seven days followed by transfer to auxin free medium produced the best rooting (62.5\%). Addition of glucose at $60 \mathrm{gl}^{-1}$ into the culture medium as the carbohydrate source increased the rooting percentage $(71.4 \%$ ) and stimulated secondary root formation. Sucrose at 60 $\mathrm{gl}^{-1}$ produced a higher number of primary roots per shoot (4.4) compared to roots per shoot in the $60 \mathrm{gl}^{-1}$ glucose treatment (2.3). Exposure of shoots to an initial seven-day dark period and localized lighting had a positive effect on rooting.
\end{abstract}

These findings can now be applied to obtain better rooting not only. in clonal plants but also in zygotic embryo cultured plants.

\section{INTRODUCTION}

The coconut palm (Cocos nucifera L.) is one of the most important tropical food and oil crops. It is still the number one commercial source of vegetable oil in Sri Lanka. Furthermore, coconut is used to produce a number of other products such as desiccated coconut, copra, shell charcoal and fibre for export and for the domestic market.

Productivity of coconut plantations could be significantly increased by using high yielding, stress tolerant planting material. Vegetative propagation employing tissue culture techniques offers a means of cloning improved planting materials within a short period of time.' With the objective of developing a reliable cloning technique for use in crop improvement programmes, studies on vegetative propagation of coconut were undertaken - using explants from the leaf, - shoot apex, root, inflorescence and the immature zygotic embryos in the 1980's. Young leaf tissues underwent direct somatic embryogenesis but further development of somatic embryos was erratic and inconsistent (Karunaratne, 1989). Palm maturity and the physiological maturity of the leaf explants were found to be critical factors 
Immature einbryo was found to be the best material for propagation research. The response from immature embryo explants has been uniform and reproducible. They produced embryogenic callus which in turi produced somatic embryos (Karunaratne and Periyapperuma, 1989). Germination of these somatic embryos leading to the production of a few plantlets was accomplished but root formation in plantlet was observed to be heterogenous (Karunaratne and Gamage, 1990). The present study was carried out to investigate the most appropriate culture conditions for in vitro rhyzogenesis in clonal plants.

\section{MATERIAL AND METHODS}

Shoots for rooting experiments were obtained by culturing shoot apices from six month-old embryo-cultured in vitro plants as it was difficult to obtain a large number of clonal shoots of coconut. Isolated shoot tips were cultured in a medium developed following the broad spectrum tissue culture trials of de Fossard (1976). The basal medium contained $\mathrm{NH}_{4} \mathrm{NO}_{3} 10, \mathrm{KNO}_{3} 10, \mathrm{CaCl}_{2} .2 \mathrm{H}_{2} \mathrm{O} 2, \mathrm{MgSO}_{4} 7 \mathrm{H}_{2} \mathrm{O} 1.5$, $\mathrm{NaH}_{2} \mathrm{PO}_{4} \cdot \mathrm{H}_{2} \mathrm{O} 1,(\mathrm{mM})$ and $\mathrm{Na}_{2} \mathrm{SO}_{4} 900, \mathrm{FeSO}_{4} .7 \mathrm{H}_{2} \mathrm{O}$ 100, $\mathrm{Na}_{2} \mathrm{EDTA}$ 100, $\mathrm{H}_{3} \mathrm{BO}_{3}$ 50, $\mathrm{MnSO}_{4} \cdot \mathrm{H}_{2} \mathrm{O} 50, \mathrm{KI} 2.5, \mathrm{CoCl}_{2} .6 \mathrm{H}_{2} \mathrm{O} 0.5, \mathrm{ZnSO}_{4} .7 \mathrm{H}_{2} \mathrm{O} 0.2, \mathrm{Na}_{2} \mathrm{MoO}_{4} .2 \mathrm{H}_{2} \mathrm{O}$ $0.1, \mathrm{CuSO}_{4} 5 \mathrm{H}_{2} \mathrm{O} 0.01$, Meso- inositol 300, Cystein $\mathrm{HCl} \mathrm{60}$, Nicotinic Acid 20, Glycine 5, Pyridoxine $\mathrm{HCl} 3$, Thiamine $\mathrm{HCl}$ 2, Vitamin C 1, Ca-Pantothenate 1, Choline Chloride 1, Riboflavin 1, Biotin 0.2, BAP 10, Kinetin 10,' PCPA 1, (UM), Sucrose $2 \%$ and Activated Charcoal $2.5 \%$.

After the shoot apices developed into shoots with at least two photosynthetic leaves, they were used for rooting experiments. Culture media for rooting experiments were based on. Eeuwens $Y_{3}$ minerals and growth factors (Eeuwens,1978). The pH of the medium was adjusted to 5.8. Agar was added at a rate of $0.6 \% \mathrm{w} / \mathrm{v}$ whenever required. Media were sterilized by autoclaving at 1 $\mathrm{kgcm}^{-2}$ for $15 \mathrm{~min}$. Shoots. dipped in auxin solutions were initially cultured in solidified media and after the roots initiated, they were transferred to liquid media. Shoot tip cultures were initially incubated in the dark for four months, and were transferred to a $16 \mathrm{hr}$ photoperiod. A minimum of 15 replicates each consisting of one shoot were used for each treatment. Data on the number of shoots which produced roots and number of primary roots per shoot. were collected after one and half months.

\section{RESULTS AND DISCUSSION}

A preliminary study carried out in this laboratory showed that various stresses could cause root initiation. Three stresses tested were (1) microwave irradiation (2) high concentration of salt $(\mathrm{NaCl})(3)$ high concentration of auxin. Among them, auxin stress showed promising results (data not presented). Therefore all the subsequent experiments were based on auxin stress. 
It is known from the literature that increased levels of auxins stimulate rhyzogenesis. Eeuwens (1978) reported root initiation from coconut inflorescence rachilla explants, when they were subcultured on to a medium containing increased levels of NAA.

Table 1. Effect of auxins pretreatment on rooting in coconut shoot culture

$\begin{array}{llll}\text { Pretreatment } \quad \text { Rooting medium } \quad \text { Rooting (\%) } & \begin{array}{l}\text { No. of } \\ \text { primary }\end{array}\end{array}$

roots

per shoot

\begin{tabular}{|c|c|c|c|}
\hline - & BM & 0.0 & 0.0 \\
\hline- & $\mathrm{BM}+\mathrm{IAA}\left(10^{-5} \mathrm{M}\right)$ & 0.0 & 0.0 \\
\hline IAA $\left(10^{-4} \mathrm{M}, 3-7\right.$ days $)$ & BM & 60.9 & 2.3 \\
\hline IAA $\left(10^{-4} \mathrm{M}, 3\right.$ days $)$ & $\mathrm{BM}+\mathrm{BAP}\left(10^{-6} \mathrm{M}\right)$ & 62.5 & 2.1 \\
\hline $\mathrm{BM}+\mathrm{IAA}\left(10^{-1} \mathrm{M}, 3\right.$ days $)$ & $\mathrm{BM}+\mathrm{BAP}$ & 0.0 & 0.0 \\
\hline NAA $\left(10^{-4} \mathrm{M}, 3\right.$ days) & $\mathrm{BM}+\mathrm{BAP}$ & 8.3 & 1.0 \\
\hline IBA (10-4 M, 3 days) & $\mathrm{BM}+\mathrm{BAP}$ & 13.3 & 4.0 \\
\hline 2, 4-D (10-3M, 7 days) & $\mathbf{B M}+\mathbf{B A P}$ & 0.0 & 0.0 \\
\hline
\end{tabular}

BM - Basal Medium containing Eeuwens $Y_{3}$ minerals and growth factors (Eeuwens 1978)

Table 1 shows that the effects of different treatments with IAA and other auxins on root initiation in coconut shoots. Roots were initiated only when shoots were dipped in $10^{-4} \mathrm{M}$ IAA, IBA and NAA solutions for three to seven days and subcultured on to auxin free media. This may be due to a high concentration of auxin, essential only at the stage of root primordia formation. The concentration of required auxin for root emergence and elongation is clearly less and the presence of high concentrations of auxin for a long period of time in the culture media may inhibit further growth of initiated roots as shown for Persea americana Mill (PleigoAlfaso, 1988) and Riber nigrum (Fentong et al.,1992). Therefore, dip treatment in concentrated auxin solutions for a short period may be preferred. In contrast to the results obtained in our experiments, there are reports on root initiation from coconut shoots when they had been subcultured in media containing $10^{-5}-10^{-6} \mathrm{M}$ NAA (Blake and Eeuwens, 1981).

As given in Table 1 the rooting percentage varied from 8.3 to 62.5 . The highest rooting percentage was observed in the IAA dip treatment. It is worthy of note that the positive effect of $10^{-4} \mathrm{M}$ IAA was suppressed when shoots were dipped in the complete culture medium containing the same amount of IAA. Dip treatment either in NAA or IBA reduced not only rooting percentage but also shoot growth. Rooting was completely suppressed in shoots in the 2,4-D dip treatment. That may be due to the use of a higher 2,4-D concentration $\left(10^{-3} \mathrm{M}\right)$ than concentrations of other auxins $\left(10^{-4} \mathrm{M}\right)$. However, more work on rooting in coconut has been reported using 
other auxins such as NAA (Blake and Eeuwens, 1981), IBA or 2,4-D (Blake and Eeuwens, 1978) and the most favourable effect was obtained with NAA.

\section{Effect of Carbohydrate Sources}

Shoots were dipped in $10^{-4} \mathrm{M}$ IAA solution ard transferred to auxin free media containing BAP $\left(10^{-6} \mathrm{M}\right)$ and different carbohydrate sources at various concentrations. With increase in glucose concentration, the number of primary roots per shoot increased, and the highest rooting percentage (71.4\%) was achieved at an optimum level of glucose $\left(60 \mathrm{gl}^{-1}\right)$ with 2.3 roots per shoot. Sucrose at $\left(60 \mathrm{gl}^{-1}\right)$ showed $62.5 \%$ rooting with an increased number of roots per shoot (4.4) (Table 2). It is important to note that shoots of $60 \mathrm{gl}^{-1}$ glucose treatment produced more secondary roots (Fig. 1) than shoots of other treatments.

Table 2. Effect of carbohydrate sources on rooting in coconut

\begin{tabular}{lccc} 
Carbohydrate source & Concentration $\left(\mathrm{gl}^{-1}\right)$ & Rooting (8) & $\begin{array}{c}\text { No. of primary } \\
\text { roots per shoot }\end{array}$ \\
\hline Glucose & 30 & 36.4 & 1.5 \\
Glucose & 60 & 71.4 & 2.3 \\
Glucose & 120 & 34.1 & 4.6 \\
Fructose & 60 & 42.9 & 3.7 \\
Sucrose & 30 & 38.5 & 2.1 \\
Sucrose & 60 & 62.5 & 4.4 \\
\hline
\end{tabular}

The positive effect of $60 \mathrm{gr}^{-1}$ glucose on rooting may be through better uptake of carbon substrate for rooting. Although the energy contents of $-60 \mathrm{gl}^{-1}$ glucose and $30 \mathrm{gl}^{-1}$ sucrose are very close, glucose was superior to sucrose as metabolic break down is probably easier compared to sucrose.

\section{Effect of an Initial Dark Period and Lighting Conditions}

For better rooting of many woody plants, shoots are normally incubated in dark during the first phase of rooting and then transferred to light for root growth.

Preliminary observations in the present work on rooting in coconut showed that inclusion of an initial dark period of seven days into auxin treatment shortened the time required for root initiation when compared to the same treatment without an initial dark period. Extending this dark.treatment to 21 days resulted in less rooting and higher shoot mortality. Furthermore, it was noted that localized lighting (only leaves) was preferred over lighting of the complete plant for rooting in coconut.

\section{CONCLUSION}

The transplantation of plants from in vitro culture to the soil is often accompanied by a fairly high mortality. Karunaratne, (1993) reported that the survival rate of embryo. cultured coconut seedlings in soil was about $43 \%$. The 
mortality rate can be reduced if these transplanted plants had well developed root systems. Hence, it is important to improve culture conditions for rooting in clonal plants of coconut.

In vitro studies on rooting in coconut have not been carried out earlier using IAA, the results emarging from the present study prove that IAA could be used. In this study more favorable results were obtanted by pre-treatment of coconut shoots in $10^{-4} \mathrm{M}$ IAA solution for three to seven days and then transferring to auxin free medium containing cytokinin than pre-treatments with other auxins. Rooting percentage as well as formation of secondary roots were found to be better in shoots cultured in a medum containing $60 \mathrm{gl}^{-1}$ of glucose. Exposure of shoots to an initial dark period and healized lighting showed positive effects on in vitro rooting in coconut shoots.

A complete technique for cloning of cocomat is yet to be perfected. Culure conditions for various developmental stages of somatic embryos are yat to be improved. Findings of this study could be applied to optimize culture conditions at the rooting stage of the cloning procedure. They could also be anplied to zygotic embryo culture of coconut in order to obtain in vitro raised seedlings with well developed root systems.

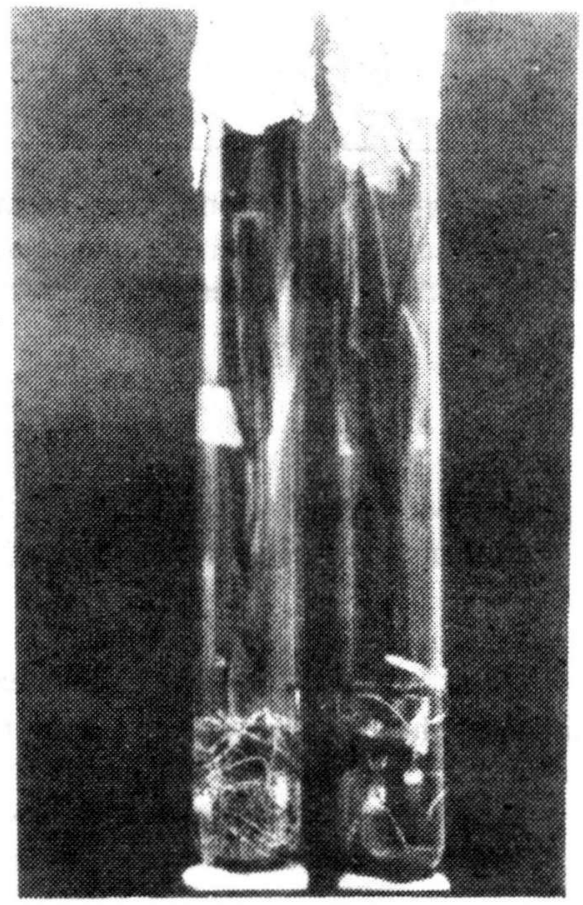

Vigure 1 Secondary root formation in the media containing (1) $60 \mathrm{gl}^{3}$ glucose (2) $60 \mathrm{gl}^{-1}$ sucrose 


\section{ACKNOWLEDGEMENT}

Our sincere thanks are due to the staff of the Tissue Culture Division, Dr. (Mrs). C.Jayasekara and Dr. R.R.A.Peries, Coconut Research Institute, Sri Lanka for their assistance in preparing the manuscript.

\section{REFERENCES}

Blake, J. and Eeuwens, C.J.(1978). Inflorescence tissue as source material for vegetative propagation of the coconut palm. In Proc. of International Conference on Cocoa and Coconut. Kunla Lumpur, 549-556.

Blake, J. and Eeuwens, C.J. (1981). Culture of coconut palm tissues with a view to propagation. In Proc. COSTED Symposium on Tissue Culture of Economically Important Plants. Ed Rao, A.N., Singapore, 145-148.

De Fossard, R.D.(1976). Tissue culture for plant propagators. 409p, University of New England Printary, Australia.

Eeuwens, C.J.(1978). Effecis of organic nutrients and hormones on growth and development of tissue explants from coconut (Cocos nucifera) and date (Phoenix dacrylifera) palms cultured in vitro. Physiol. Plant, 42: 173-178.

Fentong, M.A., Xiangsan, Z., Chunhui, G., Qiaorong, Z., Weixiu, S., Lixin,M. and Hsiao, A.I. (1992). Shoot tip culture of Riber nigrum in vitro. Journal of Horticultural Science, 67(6): 751-759.

Karunaratne, S.M. (1989). Culture of leaf explants of coconut: Development towards somatic embryogenesis. Report of the PSTC Grans 4.345, 36p.

Karunaratne, S.M. (1993). Current status of embryo and tissue culture in coconut in Sri Lanka . In Advanses in coconut research and developneent. Eds. Nair, M.K.,Khan, H.H., Gopalasundaram, P.and Bhaskara Rao, E.V.V., Oxford \& IBH publishing Co. PVT Lfd.,New Delhi, 169-172.

Kanunaratne, S.M. and Gamage, C.K.(1990). In vitro culture of immarure zygotic embryos of local varieties of coconut. In Annual Reporn of the Coconut Research Institure for Sri Lanka, 113.

Karunaratne, S. and Periyapperuma, K. (1989). Culture of immature embryos of Coconut (Cocos nucifera $\mathrm{L}$ ): Callus proliferation and somatic embryogenesis. Plant Science, 62: 247-253.

Kanunaratne, S., Gamage, C. and Kovoor, A. (1991). Leaf maturity, a critical factor in embryogensis. Journal of Plam Physiology, 139: 27-31.

Pliego-Alfaso, F.(1988). Development of an in vitro bioassay using juvenile phase stem cuttings of Persea anericana Mill. Journal of Horticulsural Science. 63(2): 295-301. 